\title{
Artikel
}

\section{Reden tot discussie over het Nederlandse planschadestelsel?}

\author{
Mr. J.H.M. (Jonathan) Huijts en prof. dr. C.W. (Chris) Backes*
}

\section{Inleiding}

In de vorige aflevering van dit tijdschrift werd andacht besteed aan de in de Omgevingswet op te nemen bepalingen over schadevergoeding bij rechtmatige overheidsdaad. Verwacht wordt dat de thans onder andere in de Wet ruimtelijke ordening (Wro), de Wet algemene bepalingen omgevingsrecht, de Ontgrondingenwet en de Tracéwet hierover opgenomen regelingen zo veel mogelijk komen te vervallen en dat de nog in werking te treden titel 4.5 van de Algemene wet bestuursrecht (Awb) hiervoor in de plaats zal treden. In het nog vorm te geven schadevergoedingshoofdstuk van de Omgevingswet (hoofdstuk 15) zullen 'enkele bijzondere bepalingen' over nadeelcompensatie worden opgenomen, die als aanvulling op de Awb-titel zullen dienen. ${ }^{1}$ Het is nog de vraag of tot deze bijzondere bepalingen ook bepalingen over planschade zullen behoren. Daartoe zouden kunnen behoren bepalingen over de limitatieve opsomming van schadeoorzaken en de forfaitaire drempel inzake het normaal maatschappelijk risico. ${ }^{2}$ In het juridische discours is reeds meermaals geschreven over de mogelijkheid om de huidige planschadepraktijk (met een eventuele wijziging in de behandeling van schaduwschade) voort te zetten onder de Wet nadeelcompensatie en

* Mr. J.H.M. (Jonathan) Huijts schrijft een proefschrift waarin hij verschillende nadeelcompensatieregelingen vergelijkt. $\mathrm{Hij}$ is verbonden aan de Universiteit Maastricht. Prof. dr. C.W. (Chris) Backes is hoogleraar bestuursrecht aan de Universiteit Maastricht.

1. H.J.M. Besselink \& J.S. Procee, Een algemene nadeelcompensatieregeling, ook in het omgevingsrecht, TO 2015, p. 78

2. J.W. van Zundert, Ontwikkelingen in planschade en nadeelcompensatie, BR 2015/47, p. 309-310. schadevergoeding bij onrechtmatige besluiten (Wns). ${ }^{3}$ De wetgever zou de vormgeving van hoofdstuk 15 van de Omgevingswet echter ook kunnen aangrijpen om het leerstuk inzake planschade fundamenteel anders vorm te geven. Ook daarvoor is, mede op basis van een blik naar onze buurlanden, al een keer gepleit. ${ }^{4}$ Het bij elkaar voegen (of vegen?) van nadeelcompensatieregelingen van heel verschillende achtergrond en traditie geeft nadrukkelijk aanleiding om hierover na te denken. In dit verband heeft het ministerie van Infrastructuur en Milieu (nogmaals) een rechtsvergelijkende verkenning gedaan naar de stelsels van planschadevergoeding in Vlaanderen en Duitsland. ${ }^{5}$ De auteurs van deze bijdrage mochten aan een deel van deze verkenning en de gevoerde gesprekken met buitenlandse deskundigen deelnemen. De blik over de grens levert in ieder geval één inzicht op. Vaak komen, zeker binnen de EU, verschillende rechtsstelsels op verschillende rechtshistorisch, rechtssystematisch en rechtscultureel bepaalde wegen tot vergelijkbare resultaten. In het planschaderecht is dat echter anders. Daar lopen de resultaten ver uiteen. Nergens in de ons omringende landen en, voor zover bekend, ook niet in andere EU-landen wordt in zo ruime mate plan-

3. Zie o.a. Besselink \& Procee 2015, p. 78-80 en 83. Vgl. B.P.M. van Ravels, De Wet nadeelcompensatie en de bijzondere wettelijke regeling van tegemoetkoming in planschade, O\&A 2013, afl. 2, p. 2-17.

4. Zie vooral B.J. van Ettekoven, Wat is normaal? Van planschade naar nadeelcompensatie (inaugurele rede), Amsterdam: Vossiuspers UvA 2011, p. 13 e.v.; terughoudend daarentegen: B.P.M. van Ravels, Het is eigenlijk heel eenvoudig ... Abstraheren, maximaliseren, objectiveren, relativeren, toerekenen en taxeren bij het beoordelen van planschade, in: A.A.J. de Gier \& G.T.M. Jurgens (red.), Goed verdedigbaar. Vernieuwing van bestuursrecht, Deventer: Kluwer 2011, p. 136 e.v.

5. Het ministerie heeft de resultaten van deze verkenning (nog) niet gepubliceerd. De auteurs van deze bijdrage is niet bekend in hoeverre daartoe wel plannen zijn. 
schadevergoeding toegekend als in Nederland. ${ }^{6}$ Met name de ruime vergoedingen voor indirecte planschade staan in schril contrast tot wat in andere landen gebruikelijk is. Voor een dichtbevolkt land met een extreem grote ruimtedruk als Nederland zou men eigenlijk het tegendeel verwachten. Ons pleidooi in deze bijdrage (zie met name par. 5) om na te denken over mogelijke principiële wijzigingen van het planschaderecht berust echter niet alleen, en zelfs niet in eerste instantie, op het inzicht dat het Nederlandse planschaderecht heel bijzonder is. Bijzonder kan immers ook bijzonder goed betekenen. Veel meer berust dit pleidooi op het feit dat ons planschadestelsel de inhoudelijke keuzes in de ruimtelijke ordening sterk lijkt te beïnvloeden. Ook dat kan wenselijk zijn. Als gemeenten afzien van toelatingsplanologie en globalere eindplannen op grond van angst voor torenhoge schadeclaims lijkt ons dat echter eerder onwenselijk te zijn. ${ }^{7}$ Reden genoeg dus om de verschillen met de ons omringende landen nog eens helder in herinnering te roepen en enkele voorstellen te doen voor een alternatieve anpak die bij de invulling van de Omgevingswet in overweging zouden kunnen worden genomen.

\section{Vlaanderen}

In Vlaanderen bestaat een relatief beperkte planschadeaansprakelijkheid voor de overheid. Dit wordt enerzijds bewerkstelligd door een beperkt planschadebegrip en anderzijds door zowel inhoudelijke als procedurele drempels die aan de aanvrager worden tegengeworpen. ${ }^{8}$ De Vlaamse planschaderegeling was oorspronkelijk opgenomen in het decreet van 18 mei 1999 houdende de organisatie van de ruimtelijke ordening (hierna: DRO). In 2009 is het DRO angepast, vernummerd en hernoemd tot de Vlaamse Codex Ruimtelijke Ordening (hierna: VCRO). De Vlaamse planschaderegeling is daarbij relatief ongewijzigd opgenomen in het zesde hoofdstuk van de tweede titel van deze codex. De precieze grondslag van de regeling is onduidelijk. In de literatuur wordt in dit kader veelvuldig gesteld dat de Vlaamse planschaderegeling een uitzondering vormt op de 'regel dat het vestigen van een erfdienstbaarheid van openbaar nut of van een eigendomsbeperking aan de

6. Zie eerder al m.n. H.J.A.M. van Geest e.a., Vergelijking planschaderegelingen (Rijksplanologische Dienst, Studierapport no. 3), Den Haag: Ministerie van VROM 2000. Zie eveneens R. Alterman, Takings International. A Comparative Perspective on Land Use Regulations and Compensation Rights, American Bar Association 2010, p. 343 in samenhang met p. 34-35: 'In contrast with the image of the Netherlands as a country that emphasizes the public interest, Dutch law grants landowners the most generous set of compensation rights for reduction in property values due to planning decisions. These cover not only direct injuries but indirect ones as well. A 2008 legislative change tempered the rights only slightly.'

7. Op deze angst zal nog worden ingegaan in par. 4 van deze bijdrage.

8. Van Geest e.a. 2000, p. 37-38. eigenaar wiens erf wordt bezwaard, normaliter ${ }^{9}$ geen recht op schadeloosstelling verleent'. ${ }^{10}$ Het is dan ook zeer waarschijnlijk dat de grondslag van de huidige planschaderegeling (deels) in de bescherming van het eigendomsrecht moet worden gezocht. Vanaf 2010 respectievelijk 2012 wordt door de hoogste Belgische rechters het 'beginsel van de gelijkheid van de burgers voor de openbare lasten' 'principieel aanvaard' in het algemeen nadeelcompensatierecht. ${ }^{11}$ Dit beginsel is vergelijkbaar met het égalitébeginsel. ${ }^{12} \mathrm{Nu}$ de VCRO eerder van kracht was en bovendien teruggaat op het DRO uit 1999, lijkt het derhalve onwaarschijnlijk dat de grondslag van de VCRO in het égalitébeginsel is gelegen.

De kernbepaling van het Vlaamse planschaderecht is art. 2.6.1 VCRO. Paragraaf 2 van deze bepaling luidt als volgt:

'Planschadevergoeding wordt toegekend wanneer, op basis van een in werking getreden ruimtelijk uitvoeringsplan, een perceel niet meer in aanmerking komt voor een vergunning om te bouwen, vermeld in artikel 4.2.1, $1^{\circ}$, of te verkavelen, terwijl het de dag voorafgaand aan de inwerkingtreding van dat definitieve plan wel in aanmerking kwam voor een vergunning om te bouwen of te verkavelen.'

In de memorie van toelichting behorende bij het decreet wordt gesteld dat een planschadevergoeding het 'verlies van de mogelijkheid om te bouwen of te verkavelen compenseert'. ${ }^{13}$ Het Vlaamse planschadebegrip is dus beperkt tot gevallen van directe planschade. Indirecte planschade wordt in Vlaanderen niet als een gevolg van de planwijziging gezien. Een eventuele vergoeding voor dergelijke schade moet derhalve via het burenrecht worden gezocht, door te stellen dat de buur die op zijn perceel gebruik maakt van de nieuwe planologische mogelijkheden, onrechtmatige hinder veroorzaakt. ${ }^{14}$ Voor zover ons bekend is en uit gesprekken met een Belgische

9. Zien wij het goed, dan duidt 'normaliter' er in dit kader op dat het recht op schadeloosstelling slechts kan ontstaan op grond van een wet, decreet of ordonnantie. Zie bijv. A. Mast e.a., Overzicht van het Belgisch administratief recht, Mechelen: Kluwer 2002, p. 333.

10. A. Mast e.a. 2002, p. 333 en 381; M. Boes, Stedenbouw en ruimtelijke ordening in het Vlaamse Gewest, Gent: Larcier 2006, p. 28 (waarin ook wordt verwezen naar relevante jurisprudentie); J.J. Bussuyt, Planschade, in: B. Hubeau e.a. (red.), Het nieuwe decreet op de ruimtelijke ordening, Brugge: die Keure 1999, p. 270-272 en 277; D. de Groote, Planschadevergoeding in België, in: L.P. Suetens e.a. (red.), Gewestplannen en planschade België en Nederland, Leuven: K.U. Leuven 1982, p. 19; A. van Oevelen, Preadvies. Schadevergoeding bij rechtmatige overheidsdaad in België, Zwolle/Antwerpen: Tjeenk Willink/Kluwer 1984, p. 126-131.

11. Hof van Cassatie 24 juni 2010, C.06.0415.N (Immo Antverpia), r.o. 2 e.v.; Grondwettelijk Hof 19 april 2012, arrest 55/2012 (Mafar), r.o. B.3.

12. W. Verrijdt, Compensatie voor schade uit foutloos overheidshandelen in België: het beginsel van de gelijkheid van de burgers voor de openbare lasten, O\&A 2013/35, p. 118

13. Vlaams Parlement 1998-99, 1332/1, p. 46. Aangezien art. 2.6.1, § 2 VCRO een letterlijke overname van art. 84, § 2 DRO betreft, zien wij geen reden waarom deze toelichting hierop niet van toepassing zou zijn.

14. Van Geest e.a. 2000, p. 11 
deskundige naar voren kwam, ${ }^{15}$ lijkt deze civiele route in de praktijk relatief weinig te worden bewandeld. Voorts lijkt, volgens onze gesprekspartners, de civiele weg in de praktijk praktisch nooit te worden gevolgd wanneer de overlastveroorzakende buur een overheidsentiteit is, aangezien het in dergelijke gevallen erg lastig zal zijn om aan te tonen dat de veroorzaakte hinder geen 'reguliere', maar onrechtmatige burenhinder betreft.

$\S \S 3$ en 4 van art. 2.6.1 VCRO werpen voorts enkele inhoudelijke drempels op door respectievelijk nadere eisen aan met name de ligging van het perceel van de aanvrager te stellen en elf situaties op te sommen waarin geen planschadevergoeding is verschuldigd. Een van de belangrijkste beperkingen is dat ingevolge art. 2.6.1, §3, onder 4 VCRO slechts planschade die ziet op de eerste 50 meter vanaf de rooilijn voor vergoeding in aanmerking komt.

Uit art. 2.6.2, § 1 VCRO blijkt dat het recht op planschadevergoeding alleen ontstaat 'bij een overdracht onder bezwarende titel van het goed, ofwel bij inbreng van het goed in een vennootschap, ofwel bij de weigering van een vergunning om te bouwen of een verkavelingsvergunning, ofwel bij het afleveren van een negatief stedenbouwkundig attest'. Uit rechtspraak van het Hof van Cassatie volgt dat 'de minderwaarde ontstaat op het ogenblik dat het plan van anleg uitwerking heeft, maar het recht op schadevergoeding slechts ontstaat vanaf het ogenblik dat een daad wordt gesteld die de minderwaarde tot uiting brengt'. ${ }^{16}$ Uit de bepaling zelf volgt voorts dat het recht op planschadevergoeding niet meer kan ontstaan vanaf het moment dat reeds vijf jaren sinds de inwerkingtreding van het plan zijn verstreken. Een reeds ontstane planschadevordering vervalt voorts een jaar na de dag waarop het recht op planschadevergoeding is ontstaan.

Uit de jurisprudentie volgen nog twee eisen die niet expliciet uit de tekst van de VCRO blijken. Allereerst had de vergunning om te bouwen die onder het nieuwe plan wordt geweigerd, onder het oude plan wel moeten kunnen worden verleend. Ten tweede moet de aanvrager aantonen dat hij reeds voor de inwerkingtreding van het nieuwe plan de intentie had om te verkavelen of te bouwen op de gronden in kwestie. ${ }^{17}$ De laatstgenoemde eis leidt ertoe dat een aanvrager in Vlaanderen geen planschadevergoeding kan verkrijgen indien zijn intentie om van de verloren bouwmogelijkheden gebruik te maken slechts blijkt uit een vergunningaanvraag die $n a$ inwerkingtreding van het nieuwe plan is ingediend. Alleen indien al vóór de planwijziging een aanvraag was ingediend of de intentie anderszins kan worden angetoond, bijvoorbeeld door een opdracht aan een bouwkundig bureau of architect die vóór de planwijziging is verstrekt, kan het wegnemen van de bouwmogelijkheid aanleiding zijn voor schadevergoeding.

Uit art. 2.6.2, § 1 VCRO blijkt verder dat de waardevermindering dient te worden geraamd als het verschil tussen de waarde van dat goed op het ogenblik van de verwerving, geactualiseerd tot aan de dag waarop het recht op schadevergoeding ontstaat, en de waarde van dat goed op het ogenblik van het ontstaan van het recht op schadevergoeding na de inwerkingtreding van dat ruimtelijk uitvoeringsplan. Deze geactualiseerde verwervingswaarde blijkt in de praktijk vaak aanzienlijk onder de daadwerkelijke waarde van het perceel tijdens de inwerkingtreding van het nieuwe plan te liggen. Zo is het denkbaar dat een woning in 1990 voor twee ton werd aangekocht en in 2015 feitelijk 3 ton waard is en de geactualiseerde verwervingswaarde slechts $€ 275.000$ betreft. Wanneer een planologische maatregel $€ 30.000$ schade (en dus een flinke waardedaling van maar liefst 10 procent) veroorzaakt en de woning derhalve nog maar $€ 270.000$ waard is, zal de conclusie moeten worden getrokken dat er geen schade is die voor vergoeding in aanmerking komt. ${ }^{18}$

Uit art. 2.6.2, § 2 VCRO volgt dat de planschadevergoeding maximaal 80 procent van de waardevermindering van de onroerende zaak zal bedragen. Directe planschade door het ontnemen van bouwmogelijkheden blijft dus tot 20 procent altijd voor rekening van de eigenaar. De vergoeding kan eventueel lager uitpakken indien de aanvrager door de planwijziging ook baten ondervindt, wegens de waardestijging van een andere onroerende zaak in hetzelfde gewest. Overigens kent het Vlaamse recht daarenboven nog een baatbelasting waarmee voordelen kunnen worden afgeroomd die door planwijzigingen ontstaan (zie art. 2.6.4 e.v. VCRO).

De belangrijkste kenmerken van het Vlaamse planschaderecht zijn:

- Planschadevergoeding is (oorspronkelijk) gebaseerd op het recht op eigendom.

- Indirecte planschade wordt niet vergoed.

- Directe planschade tot 20 procent van de geactualiseerde aankoopwaarde blijft voor rekening van de eigenaar.

- Het recht op schadevergoeding ontstaat pas als de waardevermindering zich feitelijk, bijvoorbeeld door verkoop, doet gevoelen.

- Het recht op schadevergoeding kan slechts vijf jaar na het van kracht worden van de planwijziging ontstaan. Vanaf het ontstaan van het recht op schadevergoeding heeft de eigenaar een jaar om zijn planschadevordering in te dienen.

- Het verzoek tot vergoeding wordt niet bij een bestuursorgaan, maar direct bij de rechter ingesteld.
15. Op donderdag 27 augustus 2015 hebben beide auteurs gesproken met G. van Hoorick, prof. Bestuursrecht en Milieurecht aan de Universiteit van Gent.

16. Hof van Cassatie 17 maart 2000, Justel Nummer: N-20000317-6.

17. Zie G. van Hoorick, Handboek ruimtelijk bestuursrecht, Antwerpen: Intersentia 2011, p. 182 en de jurisprudentie waarnaar daarin wordt verwezen.
18. Op papier is de woning immers zelfs $€ 5000$ meer waard dan de geactualiseerde verwervingswaarde. Zie hieromtrent eveneens Van Geest e.a. 2000 , p. 24. 


\section{Duitsland}

Duitsland kent naast een algemene planschaderegeling een groot aantal bijzondere schadevergoedingsregelingen voor schade door rechtmatig overheidshandelen op grond van ruimtelijkeordeningswetten, zoals het Bundesfernstraßengesetz of het Bundeswasserstraßengesetz. In deze bijdrage zal slechts worden ingegaan op de algemene regeling, aangezien deze zich - vanwege haar algemene karakter - het best leent voor een vergelijking met de planschaderegeling uit de Wro. Deze algemene planschaderegeling is vastgelegd in $\$ \$ 39$ jo. 44 Baugesetzbuch (hierna: BauGB). De grondslag van deze bepalingen is gelegen in de bescherming van het eigendomsrecht, niet in het égalitébeginsel. ${ }^{19}$

De kernbepaling van het Duitse recht, die de meeste overeenkomst vertoont met art. 6.1 e.v. Wro, is $\S 42$ BauGB. Het eerste lid van deze bepaling kan als volgt worden vertaald:

'Indien de planologische gebruiksmogelijkheden van een stuk grond worden opgeheven of gewijzigd en daardoor een "niet slechts marginale waardevermindering" ${ }^{20}$ van dit stuk grond ontstaat, kan de eigenaar een naar maatstaven van de volgende leden vastgestelde, geldelijke vergoeding eisen. ${ }^{21}$

Indien deze opheffing of wijziging geschiedt binnen zeven jaar na het ontstaan van de planologische mogelijkheid, bedraagt de schadevergoeding het verschil tussen de waarde van de grond met de maximale gebruiksmogelijkheden (oude planologische situatie) en de waarde van de grond met de beperkte gebruiksmogelijkheden (nieuwe planologische situatie). ${ }^{22}$ Is deze periode verstreken, dan kan slechts een planschadevergoeding worden verkregen indien de gewijzigde mogelijkheden reeds waren gerealiseerd op het moment dat de nieuwe planologische maatregel in werking trad. ${ }^{23}$ In het bijzonder bestaat er reden tot vergoeding indien door de planologische wijziging het gebruik van de reeds gerealiseerde situatie of andere mogelijkheden om deze situatie commercieel te exploiteren niet meer toegestaan zijn, of aanzienlijk worden belemmerd. De hoogte van de vergoeding wordt dan berekend als het verschil tussen de waarde die de grond had toen nog volledig gebruik kon worden gemaakt van de gerealiseerde situatie en de waarde van de grond met de beperkingen van dat

19. P. Runkel, in: Ernst/Zinkahn e.a., Baugesetzbuch, München: C.H. Beck, art. 42 BauGB, aant. 6, (online, laatst bijgewerkt in juni 2012).

20. Van Geest e.a. 2000, p. 13 legt een verband tussen 'nicht nur unwesentliche' en de Nederlandse formule 'redelijkerwijs niet te zijnen laste behoort te blijven'. Slechts een uitgebreide bestudering van de Duitse planschadejurisprudentie kan uitwijzen hoe deze termen zich tot elkaar verhouden.

21. De originele tekst luidt: 'Wird die zulässige Nutzung eines Grundstücks aufgehoben oder geändert und tritt dadurch eine nicht nur unwesentliche Wertminderung des Grundstücks ein, kann der Eigentümer nach Maßgabe der folgenden Absätze eine angemessene Entschädigung in Geld verlangen.'

22. Zie $\S 42$ lid 2 BauGB. Zie eveneens Runkel 2012, aant. 91a-91b.

23. Runkel 2012, aant. 92. gebruik onder het nieuwe planologische regime. Er wordt dus niet langer naar de maximale invulling, maar juist naar de feitelijke invulling van het oorspronkelijke planologische regime gekeken. ${ }^{24}$

Ook op grond van $\S 42$ BauGB wordt dus alleen directe planschade vergoed en dan nog slechts voor zover het om wezenlijke waardevermindering gaat. Zeven jaar na inwerkingtreding van een nieuw planologisch regime vervalt de bescherming van tot die tijd nog niet benutte bouw- en gebruiksmogelijkheden. $\$ \S 39 \mathrm{t} / \mathrm{m} 41 \mathrm{BauGB}$ bevatten daarnaast nog grondslagen voor enkele specifieke planologische schadeoorzaken. Zo voorziet $§ 40$ BauGB in een vergoeding indien een perceel een openbare bestemming krijgt.

Op grond van $\S 44$ lid 3 BauGB kunnen de hiervoor beschreven compensatiebepalingen pas worden aangewend wanneer voor de eigenaar vermogensnadeel is opgetreden, bijvoorbeeld in de vorm van waardevermindering. In tegenstelling tot het Vlaamse recht wordt niet de eis gesteld dat dit vermogensnadeel ook daadwerkelijk in de portemonnee wordt gevoeld, bijvoorbeeld door verkoop van de woning. ${ }^{25}$ De eigenaar dient de planschadeplichtige schriftelijk van zijn planschadevordering op de hoogte te stellen. Wanneer deze schriftelijke mededeling niet wordt gedaan binnen drie jaar na afloop van het jaar waarin het vermogensnadeel is opgetreden, komt de planschadevordering te vervallen. ${ }^{26}$ In beginsel gaat $\S 43$ lid 2 BauGB ervan uit dat de eigenaar en de planschadeplichtige - vaak de gemeente - overeenstemming over de vergoeding bereiken. Indien dit niet lukt, beslist de 'höhere Verwaltungsbehörde'. Deze 'rechtsgang' is in vergaande mate vergelijkbaar met wat in Nederland als administratief beroep zou worden gekwalificeerd. Hierna staat nog een gang naar de rechter open. $^{27}$

De bovenstaande alinea's laten zien dat ook in het Duitse planschadestelsel geen vergoedingen voor indirecte planschade worden toegekend. Daarom is het des te opmerkelijker dat volgens sommigen ook in Duitsland, ondanks de relatief beperkte planschadeaansprakelijkheid, nog steeds deels sprake is van een verlammende werking van het planschaderecht. Zinvolle ruimtelijke ontwikkelingen worden soms achterwege gelaten uit angst voor planschadeclaims. ${ }^{28}$

Leerstukken als abnormale en speciale last, risicoaanvaarding, schadebeperking enzovoort spelen in beginsel geen rol bij de toepassing van de genoemde Duitse bepalingen. Het is derhalve mogelijk dat iemand die een stuk grond koopt terwijl hij weet dat een planologische wijziging op komst is, toch een vergoeding op grond van

24. Zie $\S 42$ lid 3 BauGB.

25. Runkel 2012, aant. 83-85a.

26. Zie $\S 44$ lid 4 BauGB.

27. Specifiek een gang naar het 'Gerichte für Baulandsachen', zie § 217 BauGB, hetgeen een speciale afdeling van het Landgericht is (civiele rechter, tweede instantie, dus vergelijkbaar met de Nederlandse hoven).

28. Informatie ontleend aan een gesprek met prof. dr. Hans D. Jarass, dr. Boas Kümper en dr. Susan Grotefels van het 'Zentralinstitut für Raumplanung' aan de Universiteit Münster. 
bijvoorbeeld $\S 42$ BauGB zal ontvangen. ${ }^{29}$ Het vraagstuk van voorzienbaarheid in abstracto in het kader van de abnormale last zit deels 'verwerkt' in de zevenjaarstermijn van $\S 42$ lid 2 BauGB. Indien mogelijkheden tot gebruik van de grond binnen zeven jaar na van kracht worden van een Bebauungsplan door een planologische wijziging worden beperkt, kan een niet slechts marginale vermindering van waarde tot schadevergoeding leiden. Het vertrouwen in de (nog niet verwezenlijkte) gebruiksmogelijkheden wordt dus in financiële zin zeven jaar beschermd. Daarna vervalt die bescherming en wordt elke wijziging 'een normale maatschappelijke ontwikkeling'. Een dergelijk stelsel heeft nadelen, maar ook het voordeel dat over de in het Nederlandse recht soms ingewikkelde voorwaarden inzake risicoaanvaarding, schadebeperking enzovoort niet gestreden hoeft te worden en geen deskundigen nodig zijn om het al dan niet voldaan zijn van deze voorwaarden te beoordelen. Volledigheidshalve moet nog worden opgemerkt dat een planschadevergoeding in Duitsland moet worden betaald door de begunstigde van de planologische wijziging. Wanneer er geen begunstigde is, de begunstigde niet instemt met zijn rol als begunstigde, of de begunstigde zijn verplichtingen niet nakomt, dient de gemeente de planschadevergoeding uit te keren. In zowel het tweede $^{30}$ als het laatste geval bestaat er een mogelijkheid tot regres voor de gemeente. ${ }^{31}$

De voornaamste kenmerken van het Duitse planschaderecht zijn derhalve:

- Planschadevergoeding is gebaseerd op het recht op eigendom.

- In het geheel geen vergoeding voor indirecte planschade

- Wijziging van nog niet verwezenlijkte gebruiksmogelijkheden kan alleen binnen zeven jaar na het ontstaan daarvan een recht tot compensatie geven.

- Planschadevergoeding wordt betaald door de begunstigde van de planologische wijziging.

\section{Eigenheden van het Nederlandse planschaderecht}

Vergelijkt men het Nederlandse planschaderecht met beide hiervoor weergegeven stelsels, dan vallen enkele verschillen op. Terwijl vroeger, onder het regime van art. $49 \mathrm{WRO}$, vooral het rechtszekerheidsbeginsel als grondslag voor (volledige) schadevergoeding werd

29. Informatie ontleend aan een gesprek met prof. dr. Hans D. Jarass, dr. Boas Kümper en dr. Susan Grotefels van het 'Zentralinstitut für Raumplanung' aan de Universiteit Münster.

30. Uiteraard alleen als de derde onterecht van mening was dat hij niet werd begunstigd door de planologische maatregel.

31. Zie § 44 lid 1 BauGB. gezien, werd door de wetgever ${ }^{32}$ en de rechter ${ }^{33}$ angegeven dat thans het égalitébeginsel als grondslag van het planschaderecht moet worden beschouwd.

Zoals bekend komt voorts in Nederland zowel directe als indirecte planschade voor tegemoetkoming in aanmerking. Het overgrote deel van de in de praktijk betaalde vergoedingen betreft indirecte planschade. ${ }^{34}$ Hierin ligt wellicht het grootste verschil met de buurlanden, die beide geen vergoeding voor indirecte planschade kennen.

Wat de directe planschade betreft worden in alle drie de landen (nog niet verwezenlijkte) planologische gebruiksmogelijkheden beschermd. Wel bestaan er behoorlijke verschillen. In Duitsland is die bescherming beperkt tot zeven jaar na het ontstaan van de planologische mogelijkheid. Nog verder gaat het Vlaamse recht. Bouw- en gebruiksmogelijkheden die door het nieuwe plan worden ontnomen, worden alleen maar beschermd als binnen vijf jaar na inwerkingtreding van het nieuwe regime wordt angetoond dat al voorafgaande aan de wijziging een concreet voornemen bestond om gebruik te maken van deze bouw- en gebruiksmogelijkheden. In Nederland is dat niet zo. Ook al bestond een bouw- of gebruiksmogelijkheid al tal van jaren en kan de aanvrager niet aantonen dat hij ten tijde van de planwijziging concrete plannen had daar gebruik van te maken, dan krijgt hij toch een vergoeding enkel en alleen op grond van het feit dat de, mogelijk al vele tientallen jaren bestaande, bouw- en gebruiksmogelijkheden door het nieuwe regime zijn verminderd.

In Nederland wordt anspraak op tegemoetkoming wegens directe planschade echter in anzienlijke mate beperkt door het leerstuk van passieve risicoaanvaarding. Indien de overheid een planwijziging aankondigt, moet diegene wiens bouwmogelijkheden op grond van de planwijziging zullen worden ingeperkt snel handelen en concrete stappen ondernemen om deze bouwmogelijkheden te realiseren. Doorgaans zal een dergelijke stap tot realisering bestaan uit het aanvragen van de benodigde omgevingsvergunning. Uit de bijdrage van De Vries aan deze aflevering van het TO blijkt dat een termijn van circa anderhalf jaar doorgaans toereikend wordt geacht om voorzienbaarheid aan te nemen. In gemeentekringen circuleert een notitie van Bregman geschreven in opdracht van het Ministerie van Infrastructuur en Milieu, waarin onder verwijzing naar jurisprudentie wordt gesteld dat zelfs een termijn van één jaar toereikend is. Directe planschade kan derhalve in wezen slechts succesvol worden geclaimd bij plotselinge of niet

32. Kamerstukken II 2002/03, 28 916, nr. 3, p. 62-63 (MvT Wro) in samenhang met Kamerstukken II 2011/12, 33 135, nr. 3, p. 13 (MvT Wet van 28 maart 2013 tot wijziging van de Crisis- en herstelwet ...).

33. ABRvS 31 juli 2013, ECLI:NL:RVS:2013:558. Meer specifiek werd gesteld dat de drempel inzake normaal maatschappelijk risico ex art. 6.2 Wro hierop is gebaseerd. Er bestaat echter geen goede reden om aan te nemen dat de ABRvS deze mening niet ook is toegedaan inzake het overige gedeelte van de planschaderegeling uit de Wro.

34. Volgens Van Ravels had (in 2006) ongeveer 85 procent van de Afdelingsjurisprudentie inzake planschade betrekking op indirecte planschade; zie B.P.M. van Ravels, Vergoeding van planschade omstreeks 2005, Gst. (2006) 7251, p. 262 
voldoende aangekondigde wijzigingen. De in Nederland aan de burger geboden bescherming strekt hierdoor aanzienlijk minder ver dan het Duitse recht waarin de bescherming niet zo zeer is gekoppeld aan de vraag of men nog kans had om kort voor de planologische wijziging bouwmogelijkheden te verwezenlijken, maar de grondeigenaar wordt beschermd tegen te snelle wijzigingen van het planologisch regime, aangekondigd of niet. Immers, vanaf het moment dat een bouwmogelijkheid ontstaat wordt de eigenaar zeven jaar beschermd tegen wijziging.

Het Nederlandse planschaderecht lijkt op het eerste oog dus ruimer te zijn dan het recht van zowel Duitsland als Vlaanderen. De huidige invulling van de leerstukken van risicoaanvaarding en abnormale last, maakt echter dat het recht op vergoeding bij directe planschade vaak verder wordt beperkt dan in Duitsland en wellicht nog iets ruimhartiger is dan in Vlaanderen.

Een belangrijk verschil met het Vlaamse recht is het tijdstip waarop een compensatierecht ontstaat. In Vlaanderen ontstaat een compensatierecht pas als een vermogensnadeel zich daadwerkelijk realiseert, met name bij verkoop van onroerend goed, terwijl in Nederland en Duitsland een abstracte waardedaling al tot een recht op compensatie leidt, hoewel de eigenaar het nadeel helemaal nog niet in zijn portemonnee voelt en soms ook nooit zal voelen. Door middel van 'de planologische vergelijking' wordt vastgesteld of de aanvrager in een planologisch nadeligere situatie is komen te verkeren, en zo ja, of zijn perceel op het moment van het van kracht worden van het nieuwe plan minder waard is. Dat is voldoende. In Nederland leidt dit, met name bij de invulling van indirecte planschade, tot een theoretische vergelijking van juridische regimes die voor niet-juristen vaak moeilijk te begrijpen is. De feitelijke situatie zoals die door de burger wordt ervaren - speelt immers geen rol van betekenis. Slechts de geabstraheerde, objectieve, maximaal (meest ongunstig) ingevulde planologische situatie van het oude regime op een specifieke peildatum is van belang. ${ }^{35}$

Niet alleen de burger, maar ook het bestuur heeft soms moeite met de gedachte dat schadevergoeding wordt betaald voor schade die (nog) niet daadwerkelijk lijkt te worden geleden. ${ }^{36}$ Immers, een recht op tegemoetkoming in planschade ontstaat al, met name bij indirecte schade, als een theoretisch mogelijk gebruik van omliggende gronden nadeliger is dan het voorheen theoretisch mogelijk gebruik. ${ }^{37}$

Mede in dit kader wordt binnen de huidige bestuurlijke planologische praktijk reeds geruime tijd gesproken van de verlammende werking van planschadeaanspraken op

35. Zie hieromtrent bijv. ook B.P.M. van Ravels, Schadevergoeding (w.o. onrechtmatige overheidsdaad), NTB 2012/17, p. 117.

36. Idem.

37. Kritisch hierover bijv. Van Ravels 2012/17, p. 117. Zie eveneens Van Ravels 2011, p. 134-135 en Van Ettekoven 2011, p. 12-13, 15 en 17. de ruimtelijke ontwikkeling. ${ }^{38}$ Dat het bestuur ook daadwerkelijk angst hiervoor kent, wordt onder andere geillustreerd door een stuk van de gemeente Leeuwarden in het kader van de kabinetsnotitie Stelselwijziging Omgevingsrecht, waarin wordt gesteld dat 'de huidige grondexploitatiewet en de regeling planschade verlammend [werken] voor nieuwe ontwikkelingen. Planologische ruimte, ook als deze niet feitelijk wordt ingevuld, is handelswaar geworden. ${ }^{39}$ Deze angst is begrijpelijk, maar strikt juridisch gezien wellicht niet altijd te rechtvaardigen. ${ }^{40}$

Ten slotte valt op dat de stelsels in de beide buurlanden geen discussie kennen over welke (directe) planschade in redelijkheid voor rekening van de eigenaar hoort te blijven en welke schade in redelijkheid moet worden vergoed. Vage criteria, zoals de vraag of een belasting door een planwijziging behoort tot het normaal maatschappelijk risico en discussie omtrent de anwezigheid van risicoaanvaarding, spelen geen rol (van betekenis). Dat lijkt de uitvoeringskosten van deze stelsels aanzienlijk te verminderen ten opzichte van het Nederlandse stelsel. ${ }^{41}$

Al met al lijkt het Nederlandse stelsel voor directe planschade andere criteria centraal te stellen dan de stelsels van de buurlanden. Een belangrijke vraag daarbij is of de eigenaar een planwijziging heeft voorzien en dan 'nog even snel' zijn bouwmogelijkheden heeft trachten te verwezenlijken. Het overgrote deel van de planschadeverzoeken betreft echter indirecte planschade. Een beperking door passieve risicoaanvaarding is hier niet aan de orde. In de ons omringende landen wordt indirecte planschade daarentegen helemaal niet vergoed. Vooral daardoor wordt in Nederland in totaal waarschijnlijk aanzienlijk meer planschade vergoed dan in de

38. Zie over deze vrees o.a. M.K.G. Tjepkema, Tussen rechtszekerheid en flexibiliteit: contouren van het nieuwe planschaderecht, in: T. Barkhuysen, W. den Ouden \& M.K.G. Tjepkema (red.), Coulant compenseren? Over overheidsaansprakelijkheid en rechtspolitiek, Deventer: Kluwer 2012, p. 385-386 onder verwijzing naar 'Planschade: doorn in het oog van gemeenten', Stcrt. 200, 18 oktober 2004; E.J. van Baardewijk \& E.R. Hijmans, Nieuwe stijlen van gebiedsontwikkeling (deel II). Enkele aspecten van organische ontwikkeling en uitnodigingsplanologie, BR 2014/74, p. 396-397. Ook de wetgever is zich hiervan bewust, zie Kamerstukken II 2013/14, 33 962, nr. 3, p. 276-277 (MvT Omgevingswet). Regelmatig wordt deze verlammende werking ook aangehaald in het kader van een eventuele vergoeding van schaduwschade/voorbereidingsschade. Zie daaromtrent bijv. D.G.J. Sanderink, Een recht op onteigening of schadevergoeding bij schaduwschade? Een voorstel mede in het licht van art. 1 EP, TBR 2013/124, p. 842-843; Van Ravels 2013, p. 10; G.M. van den Broek, Planschadevergoeding. Het recht op planschadevergoeding bij wijziging van het planologische regime, Deventer: Kluwer 2002, p. 144.

39. Het stuk dateert van 11 april 2012 en is te raadplegen op www. internetconsultatie.nl/stelselwijziging_omgevingsrecht/reacties. Voor zover ons bekend, is geen empirische informatie beschikbaar over de vraag of, en zo ja, in welke mate daadwerkelijk van planologische maatregelen wordt afgezien vanwege de angst voor planschadevorderingen. Dat dit geregeld in de praktijk voorkomt, lijkt ons echter zeer aannemelijk.

40. Zie in dit verband de bijdrage van De Vries in dit nummer

41. Opgemerkt moet worden dat geen onderzoek naar de daadwerkelijke uitvoeringskosten van het Duitse en Vlaamse planschadestelsel is gedaan en ons daarover ook geen (vergelijkende) literatuur bekend is. In de volgende zin en bijbehorende noot wordt nog een en ander opgemerkt over de uitvoeringskosten van het Nederlandse planschadestelsel. 
ons omringende landen. ${ }^{42}$ Voorts kent het Nederlandse stelsel hoge uitvoeringskosten ${ }^{43}$ en sluit het door de geabstraheerde planologische vergelijking niet aan op de belevingswereld van de gemiddelde grondeigenaar.

\section{Suggesties voor een alternatief planschadestelsel}

In het navolgende deel van deze bijdrage zal daarom worden gezocht naar een alternatief planschadestelsel dat aan deze bezwaren tegemoetkomt. In het juridische discours is onder andere geopperd om ook in Nederland de tegemoetkoming in indirecte planschade af te schaffen. ${ }^{44}$ De vergelijking met de stelsels in Duitsland en Vlaanderen lijkt steun te bieden aan deze gedachte. Daar staat echter tegenover dat een algehele afschaffing van een vergoeding voor indirecte planschade slecht zou passen in de ontwikkeling van een algemeen stelsel van nadeelcompensatie. Vertrekpunt van art. 4:126 Awb en het daarin verwoorde égalitébeginsel is immers dat elk publiekrechtelijk handelen dat een burger in vergelijking met anderen onevenredig zwaar belast anleiding kan en zou moeten vormen voor een compensatie. Het behoeft een bijzondere rechtvaardiging om publiekrechtelijk handelen dat indirecte planschade betreft hiervan uit te zonderen, juist op een tijdstip waarop de grondslag voor égalitévergoedingen voor het overige wordt verruimd en algemeen wordt. Met andere woorden en eenvoudiger gezegd: het zou vreemd zijn om de decennialang bestaande mogelijkheid van vergoeding van indirecte planschade te schrappen in het kader van een algemene verruiming van het nadeelcompensatierecht. Er kunnen gevallen zijn waarin indirecte planschade zo zwaar en in verhouding met hetgeen iedere burger normalerwijs heeft te dulden zo bijzonder is, dat het égalitébeginsel een tegemoetkoming rechtvaardigt. Het alternatief om een burger in dergelijke gevallen, zoals in Vlaanderen, naar een dure civiele, burenrechtelijke procedure te verwijzen lijkt ons bijzonder onaantrekkelijk en onwenselijk. Dat moest met de introductie van art. 4:126 Awb nu juist worden voorkomen. Wel kan een planschaderegeling worden bedacht die, met name voor indirecte planschade, beter verzekert dat alleen nadelen worden gecompenseerd die een grondeigenaar daadwer-

42. Exacte getallen staan ons niet ter beschikking.

43. Helaas is hierover, voor zover ons bekend, weinig empirische informatie beschikbaar. Uit de MvT behorende bij de Wro blijkt dat het totale bedrag aan krachtens artikel 49 WRO toegekende schadeclaims naar schatting $€ 20$ miljoen op jaarbasis' bedraagt. Van Buuren c.s. geven aan dat onduidelijk is waarop deze schatting is gebaseerd en dat deze schatting aan de lage kant lijkt. De MvT stelt voorts: 'de behandelingskosten (gemeentelijke apparaatskosten en de kosten voordeskundigenadvies) die in beginsel voor rekening van de gemeenten komen, belopen naar schatting ongeveer $35 \%$ van dat bedrag'. Een snelle rekensom leert dus dat de behandelingskosten destijds ongeveer $€ 7$ miljoen bedroegen. Zie Kamerstukken II 2002/03, 28 916, nr. 3, p. 61 (MvT Wro) en P.J.J. van Buuren e.a., Hoofdlijnen ruimtelijk bestuursrecht, Deventer: Kluwer 2010, p. 284.

44. Van Ettekoven 2011, p. 18-19. kelijk lijdt en die abnormaal zwaar en speciaal ten opzichte van anderen zijn. Het primaire doel is dan om een planschaderegeling te introduceren die beter aansluit bij de algemene beginselen van nadeelcompensatie. Een (secundair) gevolg zal zijn dat waarschijnlijk beduidend minder compensatie zal worden betaald, de uitvoeringskosten omlaag gaan en het planschaderecht minder bepalend is voor de uit planologisch opzicht meest wenselijke redactie van een bestemmingsplan (respectievelijk omgevingsplan).

Een dergelijke omslag en verbetering van het planschaderecht kan worden gevonden indien meer de nadruk wordt gelegd op de schade die zich feitelijk manifesteert. De hierna te bespreken suggesties voor veranderingen in het planschaderecht zijn erop gefocust de juridische wereld beter aan te laten sluiten op de belevingswereld van burger en bestuur door slechts en alleen die schade te vergoeden die de anvrager daadwerkelijk in zijn beurs voelt en niet schade die potentieel zou kunnen optreden door een verandering van het planologisch kader.

Voor de nadere toelichting van onze ideeën is het zinvol te onderscheiden tussen directe en indirecte planschade. Binnen de categorie van indirecte planschade is een verdere tweedeling nodig.

\subsection{Directe planschade}

Directe planschade manifesteert zich zodra de planologische maatregel in werking treedt. Vanaf dat moment wordt de aanvrager immers beperkt in de bouw- en/of gebruiksmogelijkheden van zijn perceel. Het is meteen duidelijk wat de omvang van de verloren mogelijkheden is en daarom ook meteen mogelijk om concreet vast te stellen wat de beperkende invloed hiervan op de waarde van het perceel van de aanvrager is. Een aanvraag om tegemoetkoming in deze schade zou daarom in behandeling kunnen worden genomen vanaf het moment dat de wijziging van het planologische regime onherroepelijk is geworden. Hierbij dient te worden opgemerkt dat het weinig zinvol lijkt om - zoals in Vlaanderen wel het geval is - het recht op schadevergoeding pas te laten ontstaan op het moment van verkoop van de woning, of weigering van een omgevingsvergunning. De schade bestaat immers uit het definitief ${ }^{45}$ ontnemen van de bouw- of gebruiksmogelijkheden en heeft zich reeds met het van kracht worden van het nieuwe regime gemanifesteerd. Bovendien is de schade ook relatief eenvoudig berekenbaar.

De behandeling van dit soort schade kan derhalve in beginsel ongewijzigd blijven ten opzichte van het huidige recht. Dat wil zeggen de maximale invulling van het nieuwe planologische regime dient te worden vergeleken met de maximale invulling van het daarvoor geldende regime. De vraag is echter of de ratio van het leerstuk van passieve risicoaanvaarding kan rechtvaardigen dat daaraan een zo bepalende rol bij directe planschadeclaims zou moeten worden toegekend. Een alternatief zou zijn om, zoals in het Duitse recht gebruikelijk is,

45. Behoudens een nieuwe, toekomstige planwijziging 


\begin{tabular}{|l|l|l|llll|l|l|l|lll|}
\hline $\begin{array}{l}\text { Jaren verstreken sinds het van kracht } \\
\text { worden van een bouw- of gebruiks- } \\
\text { mogelijkheid }\end{array}$ & $0-1$ & $1-2$ & $2-3$ & $3-4$ & $4-5$ & $5-6$ & $6-7$ & $7-8$ & $8-9$ & $9-10$ & $10+$ \\
$\begin{array}{l}\text { Percentage van schade dat wegens } \\
\text { normaal maatschappelijk risico niet } \\
\text { voor vergoeding in aanmerking komt }\end{array}$ & 0 & 10 & 20 & 30 & 40 & 50 & 60 & 70 & 80 & 90 & 100 \\
\hline
\end{tabular}

geen planschadetegemoetkoming toe te kennen voor de beperking van bouw- en/of gebruiksmogelijkheden die door de aanvrager reeds een geruime tijd, bijvoorbeeld vijf of zeven jaar, onbenut zijn gelaten. ${ }^{46}$ De gedachte achter deze beperking in de tijd is dat eenieder, juist in een zo dichtbevolkt land als Nederland, erop moet rekenen dat bouw- en gebruiksmogelijkheden aan verandering onderhevig zijn en niet eeuwigdurend planologisch worden toegestaan. Dit sluit aan bij de gedachte van een redelijk denkende en handelende koper bij het huidige leerstuk van de risicoaanvaarding. Men zou voor het bepalen van deze termijn ook aan kunnen sluiten bij de tienjaarstermijn van art. 3.1 lid 2 Wro.

Ook is het denkbaar om via de band van het normaal maatschappelijk risico na verloop van tijd een minder hoge tegemoetkoming te voorzien, bijvoorbeeld in het eerste jaar sinds het van kracht worden van een bouwof gebruiksmogelijkheid 90 procent en in het negende jaar nog slechts 10 procent. Dit is het nadeelcompensatierecht niet geheel vreemd en geschiedt bijvoorbeeld onder de Nadeelcompensatieregeling verleggen kabels en leidingen in en buiten rijkswaterstaatswerken en spoorwegwerken $1999 .{ }^{47}$ Een dergelijke forfaitregeling zou er als volgt kunnen uitzien: ${ }^{48}$

De voorgestelde forfaitregeling zou overigens niet meebrengen dat in een zaak waarin bijvoorbeeld reeds drie jaar zijn verstreken sinds het van kracht worden van een bouw- of gebruiksmogelijkheid, altijd 70 procent ${ }^{49}$ van de geleden schade voor vergoeding in aanmerking komt. Sommige aspecten, zoals risicoaanvaarding, het anderszins verzekerd zijn van schade en verrekening met genoten voordelen, kunnen ertoe leiden dat een groter deel van de schade niet voor vergoeding in aanmerking komt. Eveneens zal goed moeten worden nagegaan of een deel van de gezichtspunten ${ }^{50}$ die thans worden gebruikt ter

46. Schade die ontstaat door de beperking van tijdens de wijziging van het planologische regime reeds gerealiseerde bouw- en/of gebruiksmogelijkheden komt in Duitsland ook na het verstrijken van deze zeven jaren voor tegemoetkoming in aanmerking. In Nederland wordt schade door een dergelijke beperking echter niet op grond van het planschaderecht, maar op grond van het onteigenings- en overgangsrecht behandeld.

47. Zie hiervoor specifiek art. 4 en de bijbehorende bijlagen van deze regeling.

48. De exacte percentages moeten uiteraard nauwkeurig worden vastgesteld. Mogelijkerwijs kan de gemiddelde tijdsperiode tussen opeenvolgende planologische regimes in combinatie met de bijbehorende standaardafwijking als een van de uitgangspunten daarvoor dienen.

49. $100-30=70$ procent.

50. Zie omtrent dergelijke gezichtspunten o.a. B.P.M. van Ravels, Hoe groot is het normale maatschappelijke risico? Een analyse van recente rechtspraak, NTB 2014, afl. 2, p. 4-17; de annotatie van B.P.M. van Ravels bij ABRvS 29 februari 2012, ECLI:NL:RVS:2012:BV7254 in O\&A 2012/89 (Tilburg/Vugts). bepaling van het normaal maatschappelijk risico (de normale maatschappelijke ontwikkeling, de lijn der verwachtingen, de ruimtelijke structuur van de omgeving, het gevoerde planologische beleid, de afstand tot de onroerende zaak en de omvang van het veroorzaakte nadeel) al in de bovengenoemde percentages kan worden verwerkt. Dat zou de toepassing van een dergelijke regeling namelijk eenvoudiger en minder kostbaar maken.

Een dergelijke, forfaitaire, uitwerking en toepassing van het algemene nadeelcompensatiecriterium van normaal maatschappelijk risico zou de nadruk op het leerstuk van passieve risicoaanvaarding verminderen. Dat een grondeigenaar na de aankondiging van de planwijziging nog even snel een bouwaanvraag indient, wordt dan minder bepalend. Zoals hierna nog te zien, zou deze uitwerking van het criterium van normaal maatschappelijk risico bovendien zowel bij directe als bij indirecte planschade kunnen worden toegepast. Daarmee zou het planschaderecht meer aansluiten bij het algemene nadeelcompensatierecht.

Er bestaan weinig redenen om bij de gedachtevorming over de vraag wanneer een planwijziging als een abnormale en speciale last moet worden gezien, zich te zeer te laten leiden door hetgeen thans in het planschaderecht gebruikelijk is. De vergelijking met het buitenland leert dat hier heel verschillend over kan worden gedacht. De vergelijking van verschillende in Nederland gebruikelijke nadeelcompensatieregelingen buiten het planschaderecht leert tevens dat hier ook in Nederland heel verschillend over wordt gedacht. Men kan zich niet aan de indruk onttrekken dat kortingen en drempels ter bepaling van wat als normaal maatschappelijk risico wordt gezien en dus geen abnormale last vormt ook thans tot op zekere hoogte arbitrair zijn. ${ }^{51}$ De noodzakelijke harmonisatie van het nadeelcompensatie- en het planschaderecht ter nadere invulling van art. 4:126 Awb geeft gelegenheid om de lang toegepaste (planschade)praktijk niet als vanzelfsprekend te beschouwen en met een zekere afstand na te denken over wat in de ruimtelijke ordening als een normaal maatschappelijk risico moet worden beschouwd.

\subsection{Indirecte planschade}

Bij indirecte planschade dient een nadere tweedeling te worden gemaakt. Enerzijds is er schade die wordt geleden door het enkele gegeven dat in de toekomst het

51. Zie in dit kader bijv. ook P.E.M. Franssen, Nadeelcompensatie, waar komt het vandaan en waar is het gebleven? Een stand van zaken in de praktijk, PB 2010, afl. 4, p. 6. Zie eveneens Kamerstukken II 2002/03, 28 916, nr. A, p. 21-22 (Advies RvS inzake Wro). De RvS gaf tijdens de totstandkoming van de Wro aan dat elke drempel als arbitrair kon worden gezien. 
woongenot van de aanvrager kan verminderen doordat derden (op hun aangrenzende of omliggende percelen) gebruik zouden kunnen maken van de nieuwe gebruiksen/of bouwmogelijkheden die het nieuwe planologische regime biedt. Deze schade zal worden angeduid als 'potentiële schade', aangezien slechts de wijziging van het planologische regime op papier in potentie mogelijkheden van schade inhoudt, maar nog helemaal niet gezegd is of de potentiële nadelen zich ooit ook daadwerkelijk zullen voordoen. Anderzijds is er schade die ontstaat doordat derden daadwerkelijk gebruik maken van de nieuwe gebruiks- en /of bouwmogelijkheden die het nieuwe planologische regime biedt. Deze categorie schade is te kwalificeren als 'manifeste schade'.

In geval van potentiële schade is onzeker of, en zo ja, in welke mate van de nieuwe mogelijkheden van het nieuwe planologische regime gebruik zal worden gemaakt. Deze onzekerheid kan slechts door verloop van tijd worden weggenomen, doordat de buur uiteindelijk besluit daadwerkelijk van de nieuwe mogelijkheden gebruik te maken. In dat geval is sprake van manifeste schade. De potentiële schade manifesteert zich ook op het moment dat de aanvrager zijn perceel tegen een lagere prijs verkoopt dan hij zonder de planologische maatregel had kunnen doen. ${ }^{52}$ Potentiële schade die zich niet op een van deze wijzen manifesteert, dient ons inziens, anders dan thans gebruikelijk, niet te worden vergoed. Een slechts eventuele schade is nooit een abnormaal zware en speciale last. Het stelsel van planschadetegemoetkoming dient ons inziens beperkt te blijven tot schade die zich daadwerkelijk voordoet, manifeste schade dus. Dat kan worden bewerkstelligd door indirecte planschade uitsluitend voor een eventuele tegemoetkoming in aanmerking te laten komen als deze zich, ofwel door het realiseren van bouw- en gebruiksmogelijkheden op naburige terreinen dan wel door verkoop van het eigen perceel, dan wel anderszins, heeft gemanifesteerd. In die zin valt er een parallel te trekken met het Vlaamse planschadestelsel, waarin, bij directe planschade, eveneens wordt aangenomen dat de schade als gevolg van een planologische maatregel pas voor vergoeding in aanmerking komt als deze schade zich ook daadwerkelijk manifesteert.

Potentiële schade wordt met name manifest als derden daadwerkelijk gebruik maken van de nieuwe mogelijkheden van het gewijzigde planologische regime, bijvoorbeeld doordat daadwerkelijk een nieuwe flat naast het perceel van de aanvrager wordt gebouwd. In veel gevallen zal het zo zijn dat van een deel van de nieuwe planologische mogelijkheden geen gebruik wordt gemaakt. Daarom zou bij de vaststelling van de daadwerkelijke nadelen niet moeten worden uitgegaan van de maximale invulling van het nieuwe planologische regime. Een vergelijking van de feitelijke invulling van het nieuwe planologische regime met de maximale meest ongunstige

52. Het perceel inclusief bijbehorend onroerend goed van de aanvrager daalt reeds in waarde op het moment van de wijziging van het planologische regime, maar deze schade manifesteert zich pas op het moment dat de aanvrager de waarde van zijn perceel door middel van verkoop probeert te verzilveren invulling van een eerder planologisch regime verdient de voorkeur, aangezien een dergelijke vergelijking resulteert in een begroting van de schade die beter aansluit op de feitelijke werkelijkheid.

Indien potentiële, indirecte planschade zich heeft gemanifesteerd doordat de prijs van een perceel enkel door de wijziging van het planologische regime ${ }^{53}$ is gedaald en de eigenaar tegen deze lagere prijs heeft verkocht, dient het ondervonden nadeel te worden bepaald door, net als $\mathrm{nu}$, de meest ongunstige invulling van zowel het nieuwe planologische regime als het eerdere planologische regime met elkaar te vergelijken. Vervolgens moet in een tweede stap worden nagegaan in welke mate dit nadeel zich in de daadwerkelijke verkoopprijs heeft gemanifesteerd. De nadere vormgeving van deze berekening is op verschillende wijzen mogelijk. Wij gaan hier niet nader op deze uitwerking in (dat zal op een andere plaats wel gebeuren), maar merken op dat de beperking van de uitvoeringskosten daarbij een belangrijke rol zou moeten spelen. ${ }^{54}$

Van Ravels heeft in dit kader erop gewezen dat het gevaar van schijntransacties bestaat. ${ }^{55}$ Met andere woorden: gesjoemel met koopprijzen om daardoor een planschadevergoeding in de wacht te slepen. Hoewel deze waarschuwing terecht is, lijkt de relevantie daarvan beperkt. De daadwerkelijke koopprijs speelt immers pas een rol nadat is vastgesteld dat een (potentieel) nadeel is ontstaan door de wijziging van het planologische regime. Bovendien kan het gevaar van schijntransacties worden beperkt door ruimte te laten om van de verkregen koopprijs af te wijken indien er aanwijzingen voor een schijntransactie zijn. Raadpleging van een Belgische deskundige leert dat de problematiek van schijntransacties zich in Vlaanderen niet lijkt voor te doen. De verkoop van een woning moet immers, net als in Nederland, door middel van een notariële akte worden ingeschreven. Tevens zal een sterk van de marktwaarde afwijkende koopprijs worden opgemerkt en gecorrigeerd door de rechtbank.

Voorts wijst Van Ravels erop dat een benadering als hier voorgesteld, niet goed

'in de pas lijkt te lopen met wat in het Nederlandse schadevergoedingsrecht doorgaans wordt aangenomen. De enkele reden dat de schade zich (nog) niet heeft gemanifesteerd (...) wordt daarin immers onvoldoende geacht om de rechterlijke beslissing over vergoeding van waardevermindering uit te stellen. ${ }^{56}$

Zeker gelet op de wens van de wetgever om met de Wns het schadevergoedingsrecht zo veel mogelijk te harmoniseren, is dit een belangrijk argument. Het treft echter niet de kern van de hier voorgestelde benadering. Deze

53. Op naburige percelen is dus nog geen gebruik gemaakt van nieuwe planologische bouw- en/of gebruiksmogelijkheden.

54. Uiteraard moet aan alle voorwaarden van het égalitébeginsel (als omschreven in de Wro) voldaan zijn om ook daadwerkelijk een tegemoetkoming in de planschade te ontvangen.

55. Van Ravels 2011, p. 136.

56. Van Ravels 2011, p. 135-136 
kern bestaat er namelijk uit dat het nadeel zich nog niet daadwerkelijk hoeft te hebben voltrokken om voor vergoeding in aanmerking te komen, als het maar zeker is dat de schade zich zal voordoen. Dat laatste is echter nu juist bij indirecte planschade niet het geval. Het gaat in de huidige praktijk doorgaans slechts om theoretische, potentiële schademogelijkheden die zich veelal nooit (in volle omvang) zullen manifesteren. Of een schade zal ontstaan, hangt ervan af in hoeverre een bouw- en gebruiksmogelijkheid op een buurperceel zal worden verwezenlijkt dan wel een perceel bij verkoop minder geld opbrengt dan het zonder de planologische wijziging zou hebben opgebracht.

Ook zijn nog andere vormen van manifeste, indirecte planschade denkbaar, bijvoorbeeld veroorzaakt door een bank die een hogere hypotheekrente afdwingt, omdat het bezwaarde perceel minder waard is geworden. De hoogte van deze vorm van manifeste, indirecte planschade zal doorgaans relatief eenvoudig zijn te bepalen. Op het moment dat de in het voorbeeld genoemde bank de hogere rente afdwingt, is immers duidelijk dat er schade is en hoe groot deze schade is.

\section{- Beperking van de bescherming in de loop van de tijd} en verjaringstermijnen

Ook voor indirecte planschade lijkt ons als vertrekpunt te moeten worden gekozen voor een in de tijd beperkte bescherming van het vertrouwen in een planologisch regime. Ook voor wat het gebruik en de bouwmogelijkheden op naast iemands eigendom gelegen percelen betreft is goed verdedigbaar dat eenieder erop moet rekenen dat een bepaalde planologische situatie met de tijd verandert. Terwijl in alle ons bekende landen indirecte planschade helemaal niet als 'Sonderopfer' of abnormaal zware en speciale last wordt aangemerkt, lijkt er veel voor te zeggen om in een dichtbevolkt land als Nederland wijzigingen van de planologische situatie rondom een perceel, evenals een wijziging van de bouwen gebruiksmogelijkheden van het eigen perceel, na een zeker verloop van tijd als normaal maatschappelijk risico en dus niet als een abnormale last te beschouwen. Te overwegen valt wat dat betreft dezelfde gevolgen van het tijdsverloop aan te houden die ook bij directe planschade worden voorgesteld. In overeenstemming met hetgeen hiervoor is voorgesteld, zou men bijvoorbeeld kunnen bepalen dat indirecte planschade slechts binnen een periode van tien jaar na het van kracht worden van een bouw- of gebruiksmogelijkheid voor vergoeding in aanmerking kan komen, en wel met een aflopend percentage van bijvoorbeeld 90 procent na het eerste tot 10 procent na het negende jaar. Het hanteren van dergelijke percentages zou de uitvoering van het planschaderecht aanzienlijk kunnen vereenvoudigen en de uitvoeringskosten kunnen beperken. Afhankelijk van de nadere vormgeving van een planschadestelsel dat rekening houdt met de hier gedane voorstellen, is het mogelijkerwijs noodzakelijk de huidige verjaringssystematiek ${ }^{57}$ inzake indirecte planschade eveneens aan te passen.

\section{Tot slot}

Het Nederlandse planschaderecht wijkt sterk af van het Vlaamse en Duitse planschaderecht. Het meest in het oog springende verschil is erin gelegen dat indirecte planschade slechts in Nederland voor vergoeding in aanmerking komt. Het volledig afschaffen van een vergoeding van indirecte planschade is ons inziens echter een brug te ver en zou niet passen bij de introductie van de algemene norm dat schade door rechtmatig overheidshandelen dient te worden gecompenseerd voor zover iemand daardoor in vergelijking met anderen abnormaal zwaar en bijzonder getroffen wordt. Om tegemoet te komen aan bezwaren van zowel burger als bestuur tegen het huidige Nederlandse planschaderecht is in deze bijdrage een voorstel gedaan voor een alternatieve wijze van vergoeding van indirecte planschade. Daarbij is onder meer het aan het Vlaamse planschaderecht ontleende principe dat slechts en alleen die schade die zich daadwerkelijk manifesteert voor vergoeding in aanmerking komt, leidend geweest. Bovendien is voorgesteld om, net als in het Duitse recht, de tijdsfactor een belangrijkere rol te laten spelen. Dat een planologisch regime op een gegeven moment kan wijzigen, heeft tot gevolg dat wijzigingen na een lange tijd geen abnormaal zware en speciale last kunnen betekenen. Het hanteren van vaste percentages inzake normaal maatschappelijk risico vermindert de uitvoeringslasten van het planschaderecht mogelijk aanzienlijk. Tevens zal het voorgestelde stelsel waarschijnlijk leiden tot een daling van het aantal planschadevergoedingen en de omvang daarvan. ${ }^{58}$ Ook voor directe planschade wordt voorgesteld om, vertrekkend vanuit dezelfde gedachte, het tijdsverloop met behulp van het criterium van normaal maatschappelijk risico een grotere rol te laten spelen, waardoor de nadruk op passieve risicoaanvaarding vermindert. Een afweging tussen alle voor- en nadelen van een dergelijk stelsel is niet eenvoudig te maken, temeer omdat de precieze financiële gevolgen daarvan lastig zijn in te schatten. De aanstaande veranderingen die de Aanpassingswet nadeelcompensatie en de Omgevingswet in het nadeelcompensatierecht teweeg zullen (moeten) brengen, maken het echter enerzijds noodzakelijk, maar bieden anderzijds ook de mogelijkheid om na te denken over een principieel ander, beter bij de uitgangspunten van het nadeelcompensatierecht en beter op de werkelijkheid aansluitend planschadestelsel zonder gevangen te blijven in wat tot nu toe gebruikelijk was. 